UDC 378.011.3(477)

DOI: $10.31470 / 2415-3729-2019-10-176-206$

Features of the Formation of a Specialist-Professional in the System of Higher Education in the Context of Modern Challenges and Development Prospects

\title{
Savelii Odaiskyi
}

Doctor of Philosophy in Pedagogy (Ph.D), Associate Professor

Chernivtsi Higher Professional School of Radio Electronics, Director

$\triangle 8$, Pivdenno-Kilzeva Str., Chernivtsi, Ukraine, 58032

E-mail: odaisky1965@ukr.net

ORCID: 0000-0002-9217-0204

Date of receipt of the article: October 01, 2019 Article accepted for publication: December 02, 2019

Особливості формування фахівця-професіонала в системі вищої освіти в умовах сучасних викликів та перспектив розвитку

\section{Савелій Іванович Одайський}

кандидат педагогічних наук, доцент

Чернівецьке вище професійне училище радіоелектроніки, директор $\triangle$ вул. Південно-Кільцева, 8, м. Чернівці, Україна, 58032

Дата надходження статті: 01 жовтня 2019 р. Стаття прийнята до друку: 02 грудня 2019 р.

\section{Abstract}

The article covers a number of issues related to the problem of the specialist-professional formation in the system of higher education of Ukraine, taking into account global challenges and prospects for the development of the world economy, national 
economies and modern society. In the process of scientific research, an understanding of the basic concepts of «profession», «vocational training», «formation of a specialist-professional», «IHE activity» has been formed. The role and significance of higher education in professional training of specialists, competitive in the labour market are revealed; the priority directions of development of the industry are singled out in accordance with the state educational policy requirements and the Bologna process tasks in the conditions of the European Higher Education Area formation and the integration implementation. The article pays particular attention to analysing the models of national strategies for the higher education development and selecting the model of the Ukrainian universities development strategy on the path to their promotion to world rankings, referring to the experience of autonomy, mission, results of activity and achievements of European and world universities. Consequently the research analyses of the educational institutions network during the years of Ukraine's independence, taking into account external destabilizing factors; gives the characteristic of the local IHEs' activity, including universities, during the period of reforming and modernizing the higher education system according to European standards and time requirements; determines the new approaches and directions of the IHE's activity improvement in the field of training qualified specialists for the industrial and social spheres. Moreover the article reveals the features of key trends for the modern education sphere, among them there is a globalization, the factor of ICT, the growth of non-system education, individualization and personalization of educational trajectories. It also gives the characteristic features of a competitive specialist-professional who is able to function effectively in the modern labour market. The benefits of this study are: the defined forms of the educational process organization at IHE in accordance with the Law of Ukraine «On Higher Education»; the given classification of innovative teaching methods for realizing of the educational process participants' abilities and talents, basing on the 
study of scientific and methodological literature; the determined new approaches and directions of the IHE's activity improvement in relation to the training of qualified specialists for the industrial and social spheres. On this basis, the training of competent specialist-professionals should be considered as one of the priority areas of scientific research with the definition of long-term educational strategies, including goals, tasks, scientific approaches, positions, directions and ways of their implementation in the higher education system. In the search process, the methods of theoretical research and practical implementation of this problem are used, in particular: analysis and generalization of scientific approaches and ways for improving the professionals formation process in the higher education system; international experience synthesis and comparison, normative legal acts and peculiarities of the IHE work in the professional staff training; induction and deduction when disclosing forms and methods of future specialists' educational activity, gaining their professional qualities and characteristics.

Key words: higher education system, national strategies for the higher education development, profession, vocational training, the formation of a specialist-professional, the IHE activity, the market of educational services.

\section{Referances}

1. Afanasiev, M. (2015). Forsait-vektor rukhu universytetu [Forsyth-vector of the University movement]. Vyshcha shkola High school, 9-10, 42-58 [in Ukraine].

2. Busel, V.T. (Ed.). (2009). Velykyi tlumachnyi slovnyk suchasnoi ukrainskoi movy [The Great Interpretive Dictionary of Modern Ukrainian]. Kyiv : Irpin : Perun [in Ukraine].

3. Vozniak, O. (2009). Neperervna osvita v svitli suchasnykh yevropeiskykh protsesiv [Continuing education in the light of modern European processes]. Pedahohika ta psykholohiia - Pedagogy and psychology, 468, 216 [in Ukraine].

4. Harashchuk, O., Kutsenko, V. \& Sodol, I. (2013). Pidvyshchennia yakosti pidhotovky kadriv - fundamentalna misiia 
vyshchoi shkoly [Improving the quality of training is a fundamental mission of higher education]. Vyshcha shkola - High school, 2, 2236 [in Ukraine].

5. Iefremov, V. (2015). Zberezhennia kadrovoho potentsialu vyshchoi shkoly v umovakh systemnoi kryzy v Ukraini [Preserving the staffing potential of higher education in a systemic crisis in Ukraine]. Vyshcha shkola - High school, 11-12, 75-81 [in Ukraine].

6. Kliap, M. (2015). Innovatsiini metody navchannia u VNZ yak instrument internatsionalizatsii vyshchoi osvity Ukrainy [Innovative teaching methods at universities as a tool for internationalization of higher education in Ukraine]. Vyshcha osvita Ukrainy - Higher education of Ukraine, 4, 45-53 [in Ukraine].

7. Kontseptsiia rozvytku pedahohichnoi osvity (2018). [The concept of pedagogical education development]. Vyshcha shkolaHigh school, 3, 91-111 [in Ukraine].

8. Korsak, K.V. (2011). Forsaitne planuvannia rozvytku osvity ta ekonomiky $\mathrm{v}$ epokhu nanotekhnolohii [Foresight planning of the education and economy development in the era of nanotechnology]. Problemy osvity - Problems of education, 68, 39-44 [in Ukraine].

9. Kratt, O.A., Slokva, M.H. (2005). Sehmentatsiia rynku posluh vyshchoi osvity : vykorystannia systemnoho pidkhodu: monohrafiia [Market segmentation of higher education services: using a systematic approach]. Donetsk : Yuho-Vostok, Ltd [in Ukraine].

10. Kuklin, O. (2012). Stratehichni priorytety rozvytku vyshchoi osvity Ukrainy [Strategic priorities for the development of higher education in Ukraine]. Vyshcha shkola - High school, 8, 31 [in Ukraine].

11. Kurbatov, S. (2015). Suchasnyi universytet maie buty i innovatsiinym i hlobalnym [A modern university must be both innovative and global]. Osvita Ukrainy - Education of Ukraine, 26, 29 June [in Ukraine].

12. Medynskyi, S.V. (2016). Systema profesiinoi pidhotovky fakhivtsiv fizychnoho vykhovannia i sportu u Spoluchenykh Shtatakh Ameryky: monohrafiia [The system of professional training of 
specialists in physical education and sports in the United States of America]. Chernivtsi : Rodovid [in Ukraine].

13. Nikolaienko, S. (2015). Ahrarna osvita i nauka Ukrainy v umovakh yevrointehratsii: problemy ta vyklyky [Agrarian education and science of Ukraine in the conditions of European integration: problems and challenges]. Vyshcha shkola - High school, 11-12, 19-28 [in Ukraine].

14. Patrikeieva, O., Lozova, O. \& Horbenko, S. (2018). Kontseptualni zasady rozvytku STEM-osvity v Ukraini [Conceptual bases of development of STEM-education in Ukraine]. Vyshcha shkola - High school, 9, 51-57 [in Ukraine].

15. Pro vyshchu osvitu : Zakon Ukrainy vid 01.07.2014 № 1556VII [On higher education: Law of Ukraine of 01.07.2014 № 1556VII]. Retrieved from https://zakon.rada.gov.ua/laws/show/1556-18.

16. Satsyk, V.U. (2015). poshuku efektyvnoi stratehii rozvytku vyshchoi osvity Ukrainy (analiz mozhlyvostei ta obmezhuvalnykh faktoriv) [In search of an effective strategy for the development of higher education in Ukraine (analysis of opportunities and limiting factors)]. Vyshcha osvita Ukrainy - Higher education of Ukraine, 3. 40-58 [in Ukraine].

17. Syladii, I. (2011). Yakisna osvita v konteksti upravlinnia vprovadzhenniam innovatsii [Quality education in the context of innovation management]. Vyshcha osvita Ukrainy - Higher education of Ukraine, 4, 105-112 [in Ukraine].

18. Sikorskyi, P. (2016). Zovnishni chynnyky i yikh vplyv na yakist vyshchoi osvity $\mathrm{v}$ upravlinni [External factors and their influence on the quality of higher education in management]. Vyshcha osvita Ukrainy - Higher education of Ukraine, 4, 51-57 [in Ukraine].

19. Tsarenko, I.O. (2014). Reitynhovi systemy ranzhuvannia vyshchykh navchalnykh zakladiv: ukrainski ta svitovi metodyky [Ranking systems of higher education institutions: Ukrainian and world methods]. Naukovi pratsi Kirovohradskoho natsionalnoho tekhnichnoho universytetu. Ekonomichni nauky - Scientific 
papers of Kirovograd National Technical University. Economic Sciences, 26, 56-66 Retrieved from http://nbuv.gov.ua/UJRN/ Npkntu_e_2014_26_10 [in Ukraine].

\section{Вступ}

В умовах інтеграції української освіти в європейський освітній простір проблема формування фахівця-професіонала в системі вищої освіти з урахуванням глобальних завдань i перспектив розвитку світового господарства, національних економік та суспільства набуває особливої актуальності.

У цьому зв'язку підготовка фахівців у системі вищої освіти, професійно конкурентоспроможних на національному й міжнародному ринках праці, здійснюється на засадах реалізації державної освітньої політики, зокрема Конституції України, законів України «Про вищу освіту», «Про освіту» та «Про наукову і науково-технічну діяльність», а також стратегічно важливих документів: Державної національної програми «Освіта» (Україна XXI століття), Національної доктрини розвитку освіти, Концепції розвитку освіти України на період 2015-2025 років (проект), Концепції реалізації державної політики у сфері реформування загальної середньої освіти «Нова українська школа» на період до 2029 року, Концепції розвитку педагогічної освіти, Стратегії реформування вищої освіти в Україні до 2020 року.

Виходячи 3 положень законодавчо-правових документів та враховуючи об'єктивні закономірності, особливості й перспективи соціально-економічного розвитку країни, цілі та завдання освітньої галузі, система вищої освіти має виконувати такі завдання:

- формування найбільш затребуваних компетентностей, зокрема, готовності до розв'язання складних (комплексних) практичних проблем, критичного мислення, креативності, організаційних здібностей, уміння працювати в команді, когнітивної гнучкості тощо; 
- різнобічний розвиток особистості на основі виявлених у неї нахилів і здібностей, формування ціннісних орієнтацій, задоволення інтересів і потреб;

- формування у молодого покоління цілісного наукового світогляду, загальнонаукової, загальнокультурної, технологічної, комунікативної і соціальної компетентностей на основі засвоєння системи знань, оволодіння засобами пізнавальної i практичної діяльності;

- становлення соціально зрілої і компетентної особистості, здатної здійснювати самостійний вибір і приймати відповідальні рішення в різноманітних життєвих і виробничих ситуаціях, виховання потреби і здатності до навчання упродовж усього життя, вироблення умінь практичного і творчого застосування здобутих знань;

- формування в особистості інтересу до майбутньої професії, готовності до свідомого вибору й володіння нею, забезпечення умов для життєвого й професійного самовизначення та максимально повної самореалізації особистості в обраній сфері діяльності (Патрікеєва, Лозова\&Горбенко, 2018:52-53).

У такій спосіб, посилаючись на наукові, правові та інформаційні джерела, констатуємо, що підготовка й формування фахівця-професіонала в системі вищої освіти є важливою складовою дослідницького процесу, що здійснюється вченими на засадах провідних ідей, теоретичних положень та концепцій у галузі вищої освіти.

Актуальні питання, пов'язані з розкриттям особливостей та перспектив стратегічного розвитку вищої освіти України в умовах інтеграційних процесів вивчають В. Андрущенко, А. Гуржій, Д. Дзвінчук, М. Свтух, В. Кремень, О. Куклін, В. Литвин, М. Михайльченко, С. Ніколаєнко, А. Похресник, В. Пономаренко, П. Саух. Важливі аспекти підготовки висококваліфікованих фахівців у системі вищої освіти відображено у працях Н. Абашкіної, В. Бондара, О. Гаращук, С. Гончаренка, В. Сфремова, І. Зязюна, І. Каленюка, Е. Коваленко, В. Куценко, 
В. Локшина, С. Мединського, Н. Ничкало, Т. Потапчук, О. Щербак, В. Ямкового.

Інноваційні перетворення у вищій школі щодо формування інтелектуального потенціалу українського суспільства досліджують Л. Дударенко, С. Гришко, С. Горбенко, М. Іванчук, Г. Клімова, М. Кляп, К. Корсак. О. Лозова, І. Силадій, О. Соснін, I. Татомир, Л. Федулова. Вивчення ринку освітніх послуг у системі вищої освіти здійснюють С. Бебко, Б. Буркинський, М. Бутко, А. Галаган, В. Геєць, О. Кратт, Н. Литвинова, В. Мануйлов, М. Мурашко, С. Назарко, М. Слоква, А. Федотова.

Особливості університетської освіти та вимоги до рейтингового оцінювання діяльності українських університетів 3 урахуванням міжнародного досвіду університетів США, Європи та Південно-Східної Азії аналізують М. Афанасьєв, Ю. Зіньковський, І. Золотарьова, С. Курбатов, В. Луговий, Г. Мельничук, Г. Мірських, В. Сацик, Ж. Таланова, Г. Хоружий, О. Яцунь.

Організаційні та змістові аспекти освітнього процесу в закладах освіти на основі впровадження методів і засобів ІКТ, організації інформаційно-освітнього середовища розвивають В. Биков， Т. Габай， О. Гончарова， М. Жалдак， Т. Лавриненко, О. Співаковський.

Водночас проведений аналіз вказує на недостатню розробленість у теорії і практиці вищої освіти питань, пов'язаних 3 особливостями формування фахівця-професіонала 3 вищою освітою в умовах сучасних викликів та перспектив розвитку економічної й соціокультурної сфер життєдіяльності людини і суспільства.

Стає очевидною необхідність критичного осмислення даної проблеми, іï наукового обгрунтування, розробки та практичної реалізації на основі визначення нових підходів, забезпечення умов, змісту і засобів формування в ЗВО професійно спрямованої та соціально активної особистості, готової до діяльності і праці в швидкозмінному середовищі. 
Виходячи з вищезазначеного, метою статті $€$ проаналізувати особливості формування майбутнього фахівця-професіонала в системі вищої освіти, враховуючи сучасні ризики, українські реалії та світовий досвід; висвітлити питання забезпечення якості підготовки та ефективного використання фахівців на ринку праці відповідно до вимог державної освітньої політики, завдань Болонського процесу; виявити нові підходи та напрями забезпечення умов, змісту, методів та технологій щодо підвищення рівня діяльності 3ВО з підготовки кваліфікованих фахівців та їхньої самореалізації в обраній галузі.

\section{Матеріал і методи дослідження}

У процесі пошуку використано методи теоретичного дослідження і практичної реалізації даної проблеми, зокрема: аналіз та узагальнення наукових підходів і шляхів удосконалення процесу формування професіоналів у системі вищої освіти; синтез та співставлення міжнародного досвіду, нормативноправових актів та особливостей діяльності 3ВО з підготовки професійних кадрів; індукція та дедукція при розкритті форм i методів освітньої діяльності майбутніх фахівців, набутті ними професійних якостей і ознак.

\section{Результати та їх обговорення}

На початку висвітлення окресленої проблеми доречно зосередити увагу на узагальненій характеристиці таких ключових понять як «професія», «фах», «професійна підготовка», «формування фахівця-професіонала».

Проведений аналіз дозволяє стверджувати наступне.

1. По-перше, кожне з цих понять містить домінуючі ознаки, які вказують на професійне оволодіння людиною конкретним видом трудової діяльності у рамках суспільного поділу праці; nо-друге, в літературі зазначені поняття використовуються, як правило, в синонімічному значенні через сукупність спеціальних знань, умінь, навичок, усталених цінностей, оволодіння конкретним видом занять, що вимагає певних якостей особистості, набуття досвіду, здатності і готовності особистості до включен- 
ня в стабільну виробничу діяльність у межах обраної професії (фаху); по-третє, у спорідненості підходів та за своєю змістовою сутністю ці поняття відображають процес формування фахівцяпрофесіонала в ЗВО для певної галузі діяльності, що вимагає відповідної освіти; по-четверте, в широкому контексті поняття «фахівець-професіонал» слід розглядати з позиції визначення спільних ознак та їх смислових характеристик, яких людина набуває в системі вищої освіти (Великий тлумачний словник ..., 2009; Мединський, 2016:12-13).

Наразі, здійснюючи розгляд даного аспекту проблеми, зазначимо, що формування фахівця-професіонала в системі вищої освіти розглядається нами як процес $i$ основний спосіб професійної підготовки визначеного типу самостійной людини кваліфікованого професіонала з вищою освітою, який оволодів фахом і готовий до ефективного застосування набутих знань, умінь, навичок і компетентностей в обраній професії.

Далі, продовжуючи тему дослідження, наведемо зовнішні і внутрішні ризики, які характерні для вищої освіти України в сучасних умовах іiі функціонування та розвитку (рис.1) (Ніколаєнко, 2015: 21).

Важливо також указати на сучасні виклики на шляху до створення якісної системи підготовки професіоналів у ЗВО, серед яких: принципові зміни в економіці, обумовлені зростаючою роллю знань, інформаційно-технологічною революцією, докорінними змінами в структурі ринку праці; різновекторні демографічні тенденції; інтенсифікація інформаційних потоків, що спричиняє поширення тенденції сучасної науки до експонентного зростання і поновлення знань; загальна криза системи освіти, включаючи вищу освіту; дисбаланс між нормативноправовими вимогами до компетентності випускників ЗВО та організацією їхньої професійної підготовки; зростання ролі неформальної освіти на противагу традиційній, для якої характерні інерційність, надмірна бюрократизація, статичність структур, тривалість процесу формування кадрового потенціалу; 
низький соціальний статус багатьох професійних груп фахівців, ураховуючи європейські стандарти та цінності; «витіснення» 3 ринку праці фахівців 3 інженерних, інформаційних і комп'ютерних наук тощо (Возняк, 2009:72; (Концепція ..., 2018:92-93).

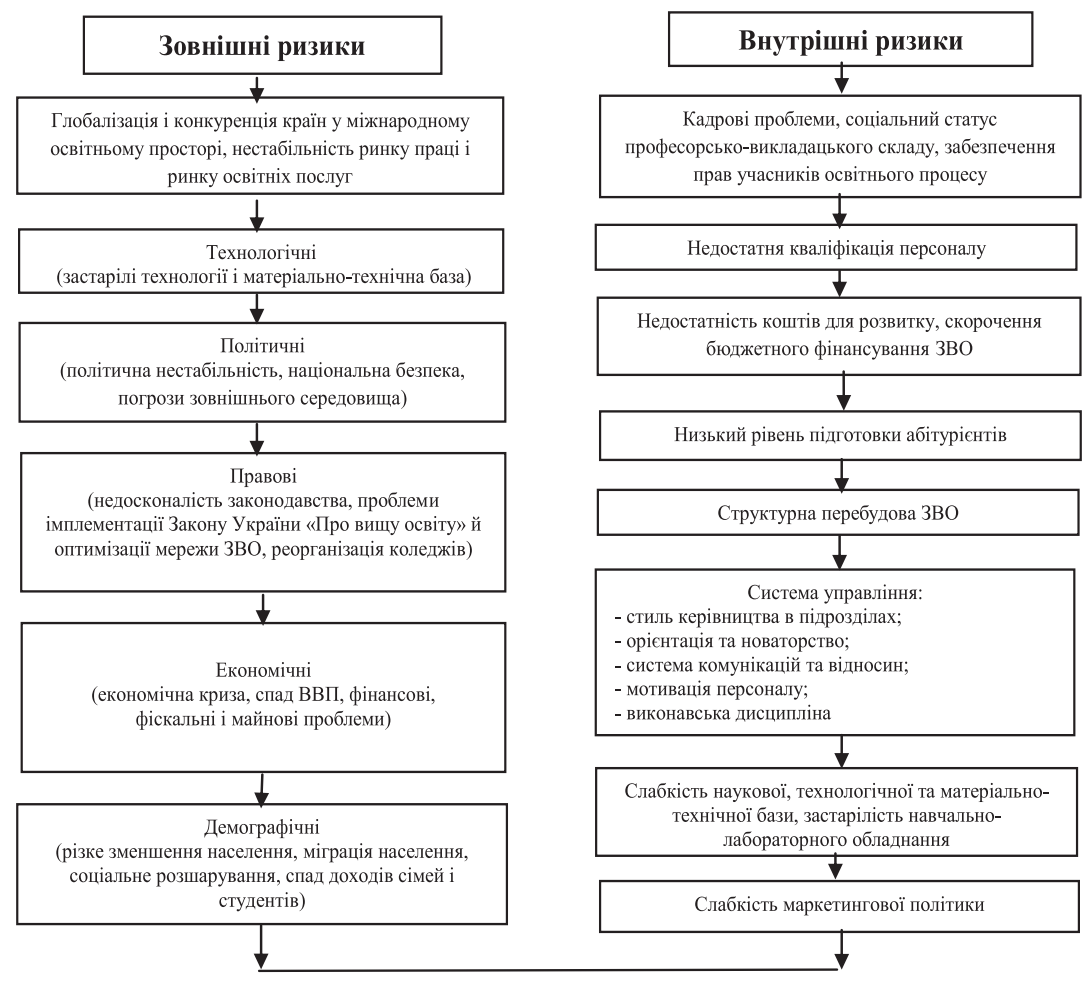

Рис. 1. Загрози у сфері вищої освіти України

Приєднуючись до позиції вчених, констатуємо, що на сучасному етапі розвитку суспільства, технологій, інформації та ринку праці значно зростає роль вищої освіти, яка має врахувати соціально-економічні процеси, суспільні трансформації і виклики часу та забезпечити виконання фундаментальної мети - 
системну підготовку фахівців-професіоналів для здійснення важливих соціальних і професійних функцій, ефективного виконання своїх обов'язків, неперервного самовдосконалення й саморозвитку в змінних умовах професійної діяльності та соціуму (Концепція ..., 2018).

При цьому зазначимо, що важливими складовими системи вищої освіти України є ЗВО всіх форм власності, рівні та ступені (кваліфікації) вищої освіти, галузі знань і спеціальності, освітні і наукові програми, стандарти освітньої діяльності та стандарти вищої освіти, органи, що здійснюють управління у сфері вищої освіти, учасники освітнього процесу (ст. 11) (Про вищу освіту, 2014).

Відтак, з урахуванням наявних завдань та суспільних потреб у підготовці кваліфікованих фахівців для галузей господарства і соціальної сфери, виокремимо пріоритетні напрями розвитку системи вищої освіти України.

До них віднесено:

- участь України в Болонському процесі та формуванні СПВО і наукових досліджень, перетворення нашої країни в повноправного члена європейської та світової спільнот;

- розроблення та упровадження державних стандартів вищої освіти 3 поглибленим вивченням та використанням європейського досвіду, його втілення в Україні у формі Національної рамки кваліфікацій;

- концентрація діяльності наукових установ і ЗВО на змісті й цілях вищої освіти, його оновлення та модернізація, включення у зміст навчання ноонаук (ноофілософії, новоісторії, нооекології, нообіології, ноофізики та ін.);

- розширення фахового потенціалу викладачів i співробітників, оволодіння новими компетенціями, неперервне підвищення кваліфікації, саморозвиток та самовдосконалення;

- скерування підготовки фахівців до діяльності в обраній сфері (професійній, науковій, дослідницькій, експериментальній та ін.), поєднання навчання та наукового дослідження; 
- зосередження уваги на порівнянні й узгодженні навчального наповнення кредитів, прийнятої за вимогами Болонського процесу системи зарахування залікових одиниць трудомісткості 3 метою сприяння мобільності всіх учасників освітнього процесу в ЗВО, які приймають іноземних студентів та делегують закордон своїх і надають можливість навчання й викладання за межами власної країни;

- поступовий рух до розроблення Національного університетського рейтингу в системі вищої освіти України як інноваційної технології на основі вироблення й використання відповідних методик, проведення необхідних обчислень якісних і кількісних параметрів та характеристик, здійснення підрахунків статистичних даних про якість освіти та їх об'єктивну порівняльну оцінку з урахуванням найбільш визнаних у світі рейтингових методик (рейтинги Таймс, SCOPUS, Шанхайський рейтинг або Академічний рейтинг університетів світу, Universitas21 та ін.), наступне включення закладу освіти до рейтингового списку;

- гуманітаризація вищої освіти та гуманізація освітнього процесу в ЗВО на засадах ціннісно-особистісної орієнтації як основи виховання i вільного розвитку особистості, яка усвідомлює свою належність до українського народу, сучасної європейської цивілізації, здатна опанувати досягнення світової та вітчизняної культури, свідомо визначає власні світоглядні позиції і духовні цінності, підготовлена до життя і діяльності в світі, що змінюється;

- здійснення національної освітньої політики у відповідності з європейськими нормами і стандартами (Велика хартія університетів, Лісабонська конвенція, Болонський процес) та впровадження задекларованих у цих документах принципів і положень в українську систему вищої освіти, зокрема певного скорочення переліку спеціальностей і напрямів підготовки фахівців, запровадження нових спеціальностей, модернізацію або закриття старих для забезпечення потреб; 
- прагматизація вищої освіти (насамперед, формування бізнес-освіти), інформатизація освіти, створення інформаційноосвітнього простору з нетрадиційними освітніми системами і технологіями (наприклад: модель електронної освітньої платформи АCCENT - «Універсальний освітній простір»);

- створення екологічно безпечних матеріалів, технологій i виробництв (ноотехнологій, надпровідно-сонячної енергетики, повної електризації всього транспорту, виробництва на основі тривимірних принтерів), новітні досягнення з етології, нейромолекулярної біології, когнітології та інших наук про людину та їі будову.

У контексті зазначеного на окрему увагу заслуговує систематизація національних стратегій розвитку вищої освіти, здійснена відомим міжнародним експертом у сфері вищої освіти С. Марджинсоном. Зокрема, дослідник запропонував перелік моделей національних стратегій розбудови висококонкурентних університетів, які здобули визнання в різних країнах світу (Сацик, 2015:47-48).

Коротко проаналізуємо їх зміст.

Перша модель - стратегія «виир» (від якісної масової вищої освіти - до створення університетів світового класу) передбачає досягання країною найвищих стандартів у сфері навчання та викладання, розширення загального доступу населення до високоякісних освітніх послуг, посилення дослідницького потенціалу університетів і в результаті поступове еволюційне виділення університетських закладів, здатних конкурувати на міжнародному рівні.

На сьогодні дана стратегія застосовується в багатьох країнах Західної Свропи, де завдяки потужному економічному потенціалу та поширеним соціальним традиціям національні уряди достатньою мірою забезпечують фінансування університетського сектору.

Друга модель - стратегія «вглиб» (від піонерних досліджень у проривних сферах знань - до створення університетів світового 
класу) - полягає у розбудові за активної інституціональної та фінансової підтримки держави глобально конкурентних університетів на базі невеликої когорти уже існуючих університетських закладів, потенційно спроможних здійснювати важливі й перспективні наукові дослідження світового рівня.

Ця стратегія активно використовувалась для розбудови університетів у Східній Азії протягом другої половини ХХ ст. (Пекінський університет, Токійський університет, Національний Тайванський університет, Сеульський університет та ін.). В наш час цю модель застосовують у країнах, які динамічно розвивають свою економіку й промисловість (Бразилія, Китай, Південна Корея, Сінгапур, Саудівська Аравія).

Третя модель - комбінована стратегія «виир» та «вглиб»$\epsilon$ певним поєднанням двох попередніх, відзначається стрімким розвитком потужного приватного університетського сектору, використовується у високорозвинених країнах світу, передусім у США, Австралії, Японії, Новій Зеландії, Південній Кореї, частково в Китаї і все більшою мірою в Західній Свропі.

Прийнятий в Україні Закон «Про вищу освіту» (2014 р.) (Про вищу освіту, 2014) за наведеною міжнародною класифікацією відображає більшою мірою елементи «иирокої» стратегії, за якої ЗВО визначають пріоритети якісного вдосконалення існуючого інституціонального поля діяльності та добирають ефективні засоби формування конкурентного освітньо-наукового середовища в даній сфері. В перспективі освітньо-наукової діяльності робиться наголос на еволюційне виокремлення висококонкурентних університетів.

Таким прогресивним шляхом розвивалась і на сьогоднішній день розвивається університетська освіта Західної Свропи, але слід наголосити на головному недоліку такої стратегії - його довготривала висока вартість, адже сподівання на позитивні зміни можуть виявити себе лише за десятки років.

У цьому аспекті для України виправданим стає альтернативний шлях - доповнення першої стратегії розробкою та 
імплементацією загальнонаціональної програми розвитку конкурентоспроможних (дослідницьких) університетів, які здійснюють свою діяльність за моделлю поєднання освіти, науки та інновацій, мають визнані наукові здобутки, сприяють інтеграції вищої освіти України в світовий освітньо-науковий простір (ст. 30) (Про вищу освіту, 2014).

Водночас стає зрозумілим, що розробка та імплементація моделі стратегії розбудови українських університетів «вшир» та «вглиб» 3 урахуванням досвіду діяльності університетів світового рівня, може стати потужним стимулом щодо вдосконалення освітньої діяльності ЗВО 3 підготовки висококваліфікованих професійних кадрів та досягнення визначних результатів на національному й міжнародному рівнях.

Разом $з$ тим, у цьому питанні важливою $є$ позиція деяких міжнародних експертів, які критикують стратегії форсованого просування університетів до складу ТОП-100 або ТОП-200 світових рейтингових показників, віддаючи перевагу ідеї розбудови так званих «флагманських» університетів - по суті, висококонкурентних національних університетських закладів 3 високою якістю освітніх послуг і помітною активною позицією у міжнародному освітньо-науковому поділі праці, які за виявленими рейтинговими позиціями можуть бути присутні у більш розширеному списку ТОП-500 найкращих університетів світу.

Такої ж думки дотримується український дослідник С. Курбатов, який стверджує, що багато українських $3 \mathrm{BO}$ за об'єктивних умов діяльності та впливу суб'єктивних факторів не можуть увійти в найближчі роки до світових рейтингів. але ж вони успішно виконують свої функції, мають власну місію, унікальні напрями діяльності та певні здобутки (Курбатов, 2015).

Серед найбільш популярних українських рейтингів визнано: ТОП-200 Україна; рейтинг Компас; рейтинг за показниками Scopus. 
Зокрема, рейтинговий проект ТОП-200 Україна є найбільш популярним серед випускників закладів освіти, адже формує достатньо повне уявлення про престижність даних ЗВО щодо високої якості вищої освіти і можливості їхнього працевлаштування в майбутньому на основі підсумування обраних критеріїв: індексу якості науково-педагогічного потенціалу (змінюється в діапазоні 0-50\%); індексу якості навчання (змінюється в діапазоні 0-30\%); індекс міжнародного визнання (змінюється в діапазоні 0-20\%) (Царенко, 2014:58).

Як бачимо, дана проблема $є$ актуальною, складною, довготривалою в часі, виходить за рамки національного дискурсу та вимагає вироблення об'єктивної державної рейтингової системи, значних економічних ресурсів, суттєвих інвестицій $\mathrm{i}$ фінансової підтримки з боку держави.

Разом 3 тим, діяльність ЗВО та його структурних підрозділів в умовах активізації стратегії інноваційного розвитку системи вищої освіти України, підпорядковуючись конкретно визначеним цілям і завданням, розглядається нами як ичілеспрямований, організаційно та змістово упорядкований прочес формування фахівців-професіоналів на основі оволодіння теоретичними і практичними знаннями, професійними вміннями $і$ навичками, цінностями та моральними нормами через осмислення власних можливостей, врахування особистих і суспільних потреб, інтересів та їх втілення в обраних видах діяльності.

Відтак, як взаємообумовлений процес, реалізація стратегічних завдань діяльності ЗВО, з одного боку, є продовженням курсу держави на розвиток вищої освіти. Натомість, 3 іншого, дає імпульс для формування професійних кадрів вищої кваліфікації, що, в свою чергу, вимагає забезпечення якості підготовки майбутніх фахівців-професіоналів у ЗВО з метою ефективного використання їхньої праці на регіональному, національному та міжнародному ринках праці. 
У контексті зазначеного звернемося до досвіду автономії європейських університетів, які спрямовують свою діяльність для вирішення таких завдань:

- самостійне формування профілю фахової підготовки шляхом запровадженням гнучких систем траєкторії навчання;

- запровадження інноваційних магістерських і докторських програм, їх напрямів і спеціалізацій;

- самостійне визначення змісту освітньо-професійних програм;

- присудження наукових ступенів та присвоєння вчених звань $з$ одержанням відповідних дипломів;

- вручення дипломів власного зразка;

- визнання дипломів про здобуті в закордонних університетах кваліфікації «магістр», «доктор філософії» (PhD), «доктор наук» та вчені звання «доцент», «профеcop»;

- самостійне визначення відповідності предметів, прослуханих студентами університету за кордоном, своїм навчальним програмам з відповідного напряму чи спеціальності, й рішення про їх зарахування;

- самостійне встановлення відповідності навчального досвіду і результатів, здобутих у межах неформального навчання, до кредитів основної програми (Сікорський, 2016:55-56).

Вищезазначене підтверджує, що надання автономії ЗВО стає важливим зовнішнім чинником, який стимулює заклад до налагодження власної діяльності, а також взаємодії та взаємообміну в міжнародному освітньо-науковому просторі, а відтак, бути більш відповідальними за результати своєї діяльності, і відповідно, кожного викладача і кожного студента. Дотримання таких вимог за сприятливих зовнішніх та внутрішніх факторів впливу, відповідних умов та змісту діяльності, безсумнівно, має забезпечити формування в ЗВО фахівців з високою професійною підготовкою на рівні потреб сучасного ринку праці. 
Далі, враховуючи об'єктивні умови реформування вищої освіти та важливість і масштабність завдань, які постали перед галуззю на сучасному етапі іiі розвитку, зосередимо увагу на висвітленні актуальних проблем діяльності 3ВО.

Проведений аналіз мережі закладів освіти показав, що за попередні роки незалежності кількість ВН3 III-IV рівнів акредитації (університетів, академій, інститутів) зросла 3146 до 351, тобто збільшилась в 2,4 рази (Куклін, 2012:31).

Цестало однієюз важливих передумов проведення оптимізації ЗВО як необхідного елементу забезпечення якості вищої освіти та підвищення іiі конкурентоспроможності в європейському освітньому середовищі. Переважно вона здійснюється з урахуванням таких факторів: ходу і результатів процесу реформування освітньої сфери та суспільних відносин у цілому, міжнародного досвіду щодо розбудови мережі ЗВО, зменшення кількості абітурієнтів у зв'язку з суттєвим падінням рівня народжуваності в Україні з початку 90-х років XX ст., реальних потреб України у фахівцях з вищою освітою в $20-\mathrm{x}-30$-х роках XXI ст.

Водночас слід врахувати вплив наявних зовнішніх дестабілізуючих чинників i насамперед: несприятливу кон'юнктуру світового ринку, проблеми в національних економіках та світовій фінансовій системі, політичну нестабільність в окремих частинах і регіонах світу, зростаюче напруження в міжнародних відносинах і військовій сфері тощо.

Разом $з$ тим, аналізуючи позиції вітчизняних учених у цьому питанні, підкреслимо необхідність створення розгалуженого інформаційно-освітнього середовища ЗВО (Б. Ахметов, О. Гончар, А. Гуржій, А. Калюжний, В. Крюков, Ю. Опанасюк), наявність якого забезпечує організаційні та змістові аспекти освітнього процесу за рахунок широкого запровадження новітніх методів і засобів IКТ, цифрових та мережевих технологій (О. Балалаєва, В. Биков, С. Бондарева, Т. Габай, М. Жалдак, Т. Лавриненко, О. Співаковський). 
Відтак, стає зрозумілим вплив ІКТ на вищу освіту та підготовку висококваліфікованих фахівців у ЗВО, які володіють сукупністю міждисциплінарних технологічних знань, сучасними засобами IКТ і готові до професійної самореалізації в обраній сфері діяльності.

У зазначеному контексті увагу привертає питання забезпечення діяльності 3 ВО на ринку освітніх послуг, який являє собою систему економічних відносин купівлі-продажу освітніх послуг з метою задоволення потреб суспільства у фахівцях, а споживачів в отриманні певної кваліфікації за відповідною спеціальністю. Головними компонентами ринку освітніх послуг є: суб'єкти ринку - покупці і продавці послуг, а з боку пропозиції - ЗВО; об’єкти ринку - послуги вищої освіти (товар), що відносяться до соціально-духовної інфраструктури; покупці послуг - міністерства і відомства, місцеві органи управління, підприємства, організації, фізичні та юридичні особи; споживачі послуг - фізичні особи (студенти) (Кратт\&Слоква, 2005:57).

Поряд 3 цим, не вдаючись до розгляду якісних характеристик суб'єктів і об'єктів ринку освітніх послуг, конкретизуємо роль та місце викладацьких кадрів в даному процесі, враховуючи їхній науково-педагогічний рівень, компетентність, кваліфікацію та досвід. Серед даної категорії працівників ЗВО перевага, безумовно, має надаватися фахівцям вищого рівня професійної діяльності, які представлені кандидатами та докторами наук, схильних до творчого пошуку, активних науковоприкладних досліджень, створення науково-педагогічних шкіл, науково-дослідних центрів, упровадження у процесі наукової та освітньо-педагогічної діяльності сучасної інформації, нових інформаційних ресурсів, інноваційних технологій та новітніх засобів комунікацій (Сфремов, 2015:79).

Отже, сучасні вимоги до професійної підготовки фахівців у ЗВО передбачаються здійснення інноваційної кадрової політики щодо розвитку кадрового потенціалу вищої школи, створення 
сприятливих умов для професійного зростання викладацьких кадрів, перебудови системи підготовки та перепідготовки науково педагогічних працівників, посилення їхньої ролі в процесі проведення реформ вищої освіти України та іiі інтеграції до міжнародного освітнього простору.

За нових реалій важливо відзначити, що сучасні вимоги щодо формування компетентного фахівця, який не тільки оволодів у ЗВО певною множиною знань, умінь, навичок і засобами IКТ, але й спроможний ефективно їх використовувати в різних областях професійної діяльності в умовах глобального інформаційно-комунікаційного середовища, зумовили появу технології форсайт-освіти, що застосовуються на методі технологічного прогнозування й планування розвитку освіти (Корсак, 2011:39-44).

Зокрема, науковцями визначені домінуючі ознаки ключових трендів для сфери сучасної освіти, серед яких:

- глобалізація: глобальні вимоги до працівників і стандарти підготовки, прихід міжнародних освітніх провайдерів на український ринок освіти;

- фактор IKT: зростання онлайн-рішень і розвиток «гібридної» педагогіки;

- зростання несистемної освіти та поява у сфері несистемної освіти нових системних рішень (освітні сервери для дітей і дорослих): розвиток Lego learning («людино, сформуй себе сама»);

- розширення ігрової компоненти в освіті;

- збільшення уваги до фізичної та психологічної безпеки освітніх рішень;

- зростання індивідуалізації та персоналізації освітніх траєкторій (Афанасьєв, 2015:44).

На цій основі, в нових умовах розвитку вищої освіти, для ЗВО визначальним постає формування конкурентоспроможних фахівців-професіоналів, які володіють системним аналізом, новим стратегічним мисленням, міцними професійними знаннями й навичками, здатні до соціальної адаптації й комунікаційної 
взаємодії в змінному виробничому середовищі, прагнуть до самонавчання, самовиховання та самовдосконалення протягом усього трудового життя, готові до активного застосування інноваційних підходів і методів у різних видах професійної діяльності, виступають носіями ідеалів демократичного суспільства.

За позиціями вчених наведемо характерні групи рис конкурентоспроможного фахівця-професіонала, здатного ефективно функціонувати на сучасному ринку праці:

- високий рівень професіоналізму й компетентності, особистісні якості, інноваційний i мотиваційний потенціал (Ф. Котлер);

- рівень професійної, соціальної й особистісної компетенції випускника, що забезпечує йому впевненість у свої силах i здатність витримувати конкуренцію на ринку праці порівняно з випускниками аналогічних 3ВО (П. Осипов);

- успішність людини у виконанні нею соціальних ролей відповідно до того, як суспільство визначає зміст цих ролей (Р. Мартенс);

- здатність фахівця більш ефективно представляти себе, свої трудові можливості роботодавцеві, уміння швидко адаптуватися до роботи в умовах нестабільності ринкових відносин ( О. Романовська);

- виявлення громадської позиції молодого фахівця, відсутність віджилих ідеологічних стереотипів, здатність до сміливості, творчості, прогресу (А. Костюченко).

Представлене узагальнення характерних рис майбутнього фахівця, професійна підготовка якого у ЗВО має відповідати сучасним вимогам ринкової економіки й особливостям соціальної сфери, потребує використання традиційних та інноваційних методів і форм освітнього процесу.

Згідно Закону України «Про вищу освіту» форми організації освітнього процесу в ЗВО визначають навчальні заняття, самостійна робота, практична підготовка та контрольні захо- 
ди (ст. 50, п.1); основними видами навчальних занять у 3 ВО є лекція, лабораторне, практичне, семінарське, індивідуальне заняття та консультація (ст. 50, п.2) (Про вищу освіту, 2014).

Водночас у процесі освітньої діяльності студенти мають оволодіти інноваційними методами і формами навчання (діалоговими, діагностичними, активними, інтерактивними, дистанційними, комп'ютерними, мультимедійними, телекомунікаційними, тренінговими, проектними), а також альтернативними освітніми технологіями, такими як: алгоритмізована, індивідуалізована, диференційована, модульна, колективна (в малих групах) тощо (Силадій, 2011:107).

Разом $з$ тим, вивчення науково-методичної літератури показало, що в теорії і практиці освітньої діяльності існують різні підходи до класифікації інноваційних методів навчання, серед яких (Кляп, 2015:48-49):

- проектні, лабораторні та інтегровані (В. Морозов);

- кооперативне, колективно-групове, ситуативне моделювання, опрацювання дискусійних питань (С. Гончаров);

- групові робота студентів, групові тренінги, «мозкова атака»; дидактичні ігри, кейс-метод, мікровикладання, «Ток-шоу»; «Коло ідей», «Акваріум» (Т. Туркот);

- технології активного, модульного та проблемного навчання, дидактичні ігри (Д. Чернілевський, І. Луцький, К. Гамрецький);

- методи конкретних ситуацій, рольова гра, проблемнопошуковий, «мозковий штурм», індивідуальні та групові тренінги, метод інтерв’ю (Н. Артикуца);

- імітаційні, мотиваційні, пізнавальні та регулятивні (А. Кочубей).

Наразі, посилаючись на Закон України «Про вищу освіту» та враховуючи позиції провідних учених у галузі вищої освіти (В. Андрущенко, І. Дичківська, В. Кремень, А. Кочубей, В. Луговий, С. Ніколаєнко, П. Саух, П. Туркот), зазначимо, що сучасні умови й цілі діяльності ЗВО вимагають застосування 
нових підходів для реалізації учасниками освітнього процесу їхніх здібностей і талантів, а саме:

1) забезпечення багатоваріантності новітніх методів навчання, спрямованих на якісне засвоєння знань студентами, розвиток їх інтелектуальної діяльності, формування вмінь та навичок критичного мислення, актуалізації професійної проблеми та вибору оптимального способу іiі практичної реалізації, набуття якостей, що стануть у нагоді в майбутньому професійному житті;

2) створення в кожному ЗВО належної бази найбільш часто використовуваних інноваційних методів, прийомів, технологій освітньої діяльності в контексті компетентнісного підходу та творчості;

3) врахування в діяльнісному аспекті категорій учасників освітнього процесу: наукових, науково-педагогічних та педагогічних працівників, здобувачів вищої освіти та інших осіб, які навчаються в ЗВО, фахівців-практиків, інших працівників 3ВО, роботодавців (ст. 52); специфіки та складу науково-педагогічних, педагогічних та наукових працівників (ст. 53); рівнів та ступенів вищої освіти (ст. 5, п. 1); одержаної кваліфікації (ст. 7, п. 3); особливостей спеціальностей, за якими здійснюється підготовка фахівців у конкретному ЗВО (ст. 26) (Про вищу освіту, 2014).

Зазначене свідчить про необхідність розроблення вітчизняної концепції розвитку ЗВО, яка б: 1) реалізувала на практиці світові освітні тенденції, Болонські домовленості в галузі вищої освіти й мобільності та здобутки національної вищої школи; 2) врахувала сучасні внутрішні й зовнішні фактори впливу на діяльність 3ВО; 3) закцентувала головну увагу на засобах, способах, формах, змісті і напрямах професійної підготовки фахівців у ЗВО за відповідними освітніми ступенями на основі державних стандартів вищої освіти, переліку галузей знань і переліку спеціальностей, за якими здійснюється підготовка здобувачів вищої освіти в Україні. 


\section{Висновки}

Підсумовуючи вищевикладене, зазначимо, що формування професійного конкурентоспроможного фахівця в системі вищої освіти сьогодні набуває актуальності і гостроти в контексті динамічних змін техніки та технологій у постіндустріальному суспільстві, зростання впливу глобалізації на всі аспекти життєдіяльності людини, поглиблення інтеграційних процесів у європейському освітньому просторі та врахування особливостей реформування вищої освіти України у відповідності з принципами Болонської декларації, державною політикою, національними освітніми традиціями та досягненнями в галузі освіти і науки впродовж багатьох років становлення й розвитку.

На цій основі підготовку компетентних фахівців-професіоналів слід віднести до одного 3 пріоритетних напрямів наукових досліджень 3 визначенням довгострокових освітніх стратегій, включаючи цілі, завдання, наукові підходи, положення, напрями та шляхи їх реалізації в системі вищої освіти. Водночас має бути сформовано чітке усвідомлення того, що від рівня професійної підготовки та індивідуальної самореалізації особистості залежить прискорення соціального й науково-технічного прогресу країни, розширення і відтворення інтелектуального та культурного потенціалу українського народу, підвищення ефективності діяльності національних інститутів економіки, політики і культури, професіоналізація та соціалізація людини як суб'єкта трудової діяльності, вільної й автономної особистості, готової до сприйняття загальнолюдських моральних цінностей, постійного самовдосконалення й самоствердження.

\section{Література}

1. Афанасьєв М. Форсайт-вектор руху університету. Вищза школа. 2015. № 9-10. С. 42-58.

2. Великий тлумачний словник сучасної української мови (3. Дод., допов. на CD) / Уклад. і голов. ред. В.Т. Бусел. Київ : Ірпінь : Перун, 2009. 1736 с. 
3. Возняк О. Неперервна освіта в світлі сучасних європейських процесів. Педагогіка та психологія. Чернігів. ЧНУ. 2009. Вип. 468. 216 с.

4. Гаращук О., Куценко В., Содоль I. Підвищення якості підготовки кадрів - фундаментальна місія вищої школи. Вища школа. 2013. № 2. С. 22-36.

5. Сфремов В. Збереження кадрового потенціалу вищої школи в умовах системної кризи в Україні. Вищза школа. 2015. № 11-12. С. 75-81.

6. Кляп М. Інноваційні методи навчання у ВНЗ як інструмент інтернаціоналізації вищої освіти України. Вищза освіта України. 2015. № 4. С. 45-53.

7. Концепція розвитку педагогічної освіти. Вищуа освіта. 2018. № 3. С. 91-111.

8. Корсак К.В. Форсайтне планування розвитку освіти та економіки в епоху нанотехнологій. Проблеми освіти. 2011. Вип. 68. С. 39-44.

9. Кратт О.А., Слоква М.Г. Сегментація ринку послуг вищої освіти : використання системного підходу: монографія. Донецьк : Юго-Восток, Лтд, 2005. 207 с.

10. Куклін О. Стратегічні пріоритети розвитку вищої освіти України. Вищза школа. 2012. № 8. С. 31.

11. Курбатов С. Сучасний університет має бути i інноваційним і глобальним. Освіта України. 2015. № 26. 29 червня.

12. Мединський С.В. Система професійної підготовки фахівців фізичного виховання і спорту у Сполучених Штатах Америки: монографія. Чернівці : Родовід, 2016. 472 с.

13. Ніколаєнко С. Аграрна освіта і наука України в умовах євроінтеграції: проблеми та виклики. Вищза освіта. 2015. № 1112. C. $19-28$.

14. Патрікеєва О., Лозова О., Горбенко С. Концептуальні засади розвитку STEM-освіти в Україні. Вища школа. 2018. № 9. C. 51-57. 
15. Про вищу освіту : Закон України від 01.07.2014 № 1556VII URL: https://zakon.rada.gov.ua/laws/show/1556-18 (Дата звернення 12.09.2019).

16. Сацик В. У пошуку ефективної стратегії розвитку вищої освіти України (аналіз можливостей та обмежувальних факторів). Вищза освіта України. 2015. № 3. С.40-58.

17. Силадій І. Якісна освіта в контексті управління впровадженням інновацій. Вищза освіта України. 2011. № 4. С. 105-112.

18. Сікорський П. Зовнішні чинники і їх вплив на якість вищої освіти в управлінні. Вищуа освіта Украӥни. 2016. № 4. C. 51-57.

19. Царенко I.О. Рейтингові системи ранжування вищих навчальних закладів: українські та світові методики. Наукові пращі Кіровоградського національного технічного університету. Економічні науки: зб. наук. пр. Кіровоград : КНТУ, 2014. Вип. 26. C. 56-66. URL: http://nbuv.gov.ua/UJRN/Npkntu_e_2014_26_10 (Дата звернення 13.09.2019).

\section{Одайський C.I.}

Особливості формування фахівця-професіонала в системі вищої освіти в умовах сучасних викликів та перспектив розвитку

\section{Анотація}

У статті висвітлюється коло питань, пов'язаних 3 проблемою формування фахівця-професіонала в системі вищої освіти України з урахуванням глобальних викликів та перспектив розвитку світового господарства, національних економік і сучасного суспільства. У процесі наукового пошуку сформовано розуміння базових понять «професія», «фах», «професійна підготовка», «формування фахівця-професіонала», «діяльність 3ВО». Розкривається роль і значення вищої освіти в професійній 
підготовці фахівців, конкурентоспроможних на ринку праці; виокремлюються пріоритетні напрями розвитку галузі згідно вимог державної освітньої політики та завдань Болонського процесу в умовах формування Свропейського простору вищої освіти та здійснення інтеграції.

Окрему увагу приділено аналізу моделей національних стратегій розвитку вищої освіти та вибору моделі стратегії розбудови українських університетів на шляху їх просування до світових рейтингів, посилаючись на досвід автономії, місію, результати діяльності та здобутки європейських і світових університетів.

Подається аналіз мережі закладів освітиза роки незалежності України з урахуванням зовнішніх дестабілізуючих чинників; подається характеристика діяльності вітчизняних ЗВО, включаючи університети, в період реформування й модернізації системи вищої освіти за європейськими стандартами та вимогами часу; визначаються нові підходи і напрями вдосконалення діяльності ЗВО щодо підготовки кваліфікованих фахівців для виробничої й соціальної сфер.

Розкрито ознаки ключових трендів для сфери сучасної освіти, серед яких домінують глобалізація, фактор IКТ, зростання несистемної освіти, індивідуалізації та персоналізації освітніх траєкторій; наведено характерні групи рис конкурентоспроможного фахівця-професіонала, здатного ефективно функціонувати на сучасному ринку праці. Розкрито згідно Закону України «Про вищу освіту» форми організації освітнього процесу в ЗВО; на основі вивчення науково-методичної літератури представлено класифікацію інноваційних методів навчання для реалізації учасниками освітнього процесу їхніх здібностей і талантів. Визначаються нові підходи і напрями вдосконалення діяльності ЗВО щодо підготовки кваліфікованих фахівців для виробничої й соціальної сфер. На цій основі підготовку компетентних фахівців-професіоналів слід віднести до одного 3 пріоритетних напрямів наукових досліджень 3 визначенням 
довгострокових освітніх стратегій, включаючи цілі, завдання, наукові підходи, положення, напрями та шляхи їх реалізації в системі вищої освіти.

У процесі пошуку використано методи теоретичного дослідження і практичної реалізації даної проблеми, зокрема: аналіз та узагальнення наукових підходів і шляхів удосконалення процесу формування професіоналів у системі вищої освіти; синтез та співставлення міжнародного досвіду, нормативноправових актів та особливостей діяльності 3ВО з підготовки професійних кадрів; індукція та дедукція при розкритті форм і методів освітньої діяльності майбутніх фахівців, набутті ними професійних якостей і ознак.

Ключові слова: система вищої освіти, національні стратегії розвитку вищої освіти, професія, фах, професійна підготовка, формування фахівця-професіонала, діяльність ЗВО, ринок освітніх послуг.

\section{Одайский С.И.}

\section{Особенности формирования специалиста-профессионала в си- стеме высшего образования в условиях современных вызовов и перспектив развития}

\section{Аннотация}

В статье освещается круг вопросов, связанных с проблемой формирования специалиста-профессионала в системе высшего образования Украины с учетом глобальных вызовов и перспектив развития мирового хозяйства, национальных экономик и современного общества. В процессе научного поиска сформирован понимание базовых понятий «профессия», «специальность», «профессиональная подготовка», «формирование специалистапрофессионала», «деятельность ЗВО». Раскрывается роль и значение высшего образования в профессиональной подготовке 
специалистов, конкурентоспособных на рынке труда; выделяются приоритетные направления развития отрасли в соответствии с требованиями государственной образовательной политики и задач Болонского процесса в условиях формирования Европейского пространства высшего образования и осуществления интеграции.

Особое внимание уделено анализу моделей национальных стратегий развития высшего образования и выбора модели стратегии развития украинских университетов на пути их продвижения в мировые рейтинги, ссылаясь на опыт автономии, миссию, результаты деятельности и достижения европейских и мировых университетов.

Дается анализ сети учебных заведений за годы независимости Украины с учетом внешних дестабилизирующих факторов; дается характеристика деятельности отечественных 3ВО, включая университеты, в период реформирования и модернизации системы высшего образования по европейским стандартам и требованиям времени; определяются новые подходы и направления совершенствования деятельности ЗВО по подготовке квалифицированных специалистов для производственной и социальной сфер.

Раскрыто признаки ключевых трендов для сферы современного образования, среди которых доминируют глобализация, фактор ИКТ, рост несистемной образования, индивидуализации и персонализации образовательных траекторий; приведены характерные группы рис конкурентоспособного специалистапрофессионала, способного эффективно функционировать на современном рынке труда. Раскрыто согласно Закону Украины «О высшем образовании» формы организации образовательного процесса в 3ВО; на основе изучения научно-методической литературы представлена классификация инновационных методов обучения для реализации участниками образовательного процесса их способностей и талантов. Определяются новые подходы и направления совершенствования деятельности ЗВО по подго- 
товке квалифицированных специалистов для производственной и социальной сфер. На этой основе подготовку компетентных специалистов-профессионалов следует отнести к одному из приоритетных направлений научных исследований по определению долгосрочных образовательных стратегий, включая цели, задачи, научные подходы, положения, направления и пути их реализации в системе высшего образования.

Ключевые слова: система высшего образования, национальные стратегии развития высшего образования, профессия, специальность, профессиональная подготовка, формирование специалиста-профессионала, деятельность ЗВО, рынок образовательных услуг. 